\title{
Role of ACE2 And TMPRSS2 Protease In SARS-CoV-2 Dynamics Among Household Contacts of PCR-Confirmed Cases: Impact of A Combined Serological Signature Analysis On Diagnosis
}

\section{Jesús Poch-Páez}

Hospital Universitario Materno Infantil de Canarias

yeray nóvoa-medina ( $\square$ yeraynm@hotmail.com)

Complejo Hospitalario Materno-Insular https://orcid.org/0000-0002-9564-0654

Abián Montesdeoca-Melián

Canary Islands Health Service: Servicio Canario de Salud

Araceli Hernández-Betancor

Complejo Hospitalario Materno-Insular

Francisco J. Rodríguez-Esparragón

Complejo Hospitalario Doctor Negrin: Hospital Universitario de Gran Canaria Dr Negrin

\section{Svetlana Pavlovic-Nesic}

Complejo Hospitalario Materno-Insular

\section{Melisa Hernández-Febles}

Dr Negrin University Hospital of Gran Canaria: Hospital Universitario de Gran Canaria Dr Negrin

Jesús M. González-Martín

Dr Negrin University Hospital of Gran Canaria: Hospital Universitario de Gran Canaria Dr Negrin

Laura Cappiello

Dr Negrin University Hospital of Gran Canaria: Hospital Universitario de Gran Canaria Dr Negrin

\section{Valewska Wallis-Gómez}

Complejo Hospitalario Materno-Insular

Joaquin Quiralte-Castillo

Complejo Hospitalario Materno-Insular

Alejandro Maján-Rodríguez

Complejo Hospitalario Materno-Insular

Martín Castillo De Vera

Canary Islands Health Service: Servicio Canario de Salud

\section{Maria T. Angulo-Moreno}

Complejo Hospitalario Materno-Insular

\section{Augusto González-Pérez}

Complejo Hospitalario Materno-Insular

\section{Asunción Rodríguez}

Complejo Hospitalario Materno-Insular

\section{Zelidety Espinel-Padrón}

Complejo Hospitalario Materno-Insular

\section{Elisa M. Canino-Calderín}

Complejo Hospitalario Materno-Insular

\section{Irina Manzano-Gracia}

Complejo Hospitalario Materno-Insular

Elena Colino-Gil

Complejo Hospitalario Materno-Insular

Ana I. Reyes Dominguez 
Complejo Hospitalario Materno-Insular

Irina Moreno-Afonso

Complejo Hospitalario Materno-Insular

Raquel McLaughlin-García

Complejo Hospitalario Materno-Insular

Maria L. Naranjo-Báez

Canary Islands Health Service: Servicio Canario de Salud

Ana Bordes-Benitez

Dr Negrin University Hospital of Gran Canaria: Hospital Universitario de Gran Canaria Dr Negrin

Isabel De Miguel-Martínez

Complejo Hospitalario Materno-Insular

Carlos Rodríguez-Gallego

Dr Negrin University Hospital of Gran Canaria: Hospital Universitario de Gran Canaria Dr Negrin

Luis Peña-Quintana

Complejo Hospitalario Materno-Insular

\section{Research article}

Keywords: COVID-19, SARS-CoV-2, ECA2, TMPRSS22, household, serology, children

Posted Date: July 28th, 2021

DOI: https://doi.org/10.21203/rs.3.rs-753446/v1

License: @ (1) This work is licensed under a Creative Commons Attribution 4.0 International License. Read Full License 


\section{Abstract}

Background: To examine the hypothesis that ACE2 and TMPRSS2 expression are related to disease susceptibility and severity across age groups and to evaluate the role children play in the household transmission of SARS-CoV-2.

Methods: We used a combined serological strategy to confirm past infection in subjects diagnosed with COVID-19 between march $10^{\text {th }}$ and June $2^{\text {nd }} 2020$ and to evaluate their household members. We also quantified ACE2 and TPMRSS 2 expression from saliva. A total of 258 households were included in the study, for a total of 650 volunteers (including 89 children aged under 18 years of age).

Results: Our combined testing strategy increased our sensibility by $10 \%$. Antibody indexes decreased with age in children and increased with age in adults. They also increased with disease severity. ACE2 expression was slightly increased in younger children. ACE2 was not related to any other factors. We did not find any relationship between TMPRSS2 expression and any of the studied factors. Children are less frequently infected by SARS-CoV-2 $(\mathrm{OR}=0,56)$, they present fewer symptoms and decreased severity. Age and sharing the bedroom with an index case increases the risk of acquiring the infection. The risk in adults increases with age, whereas in children, it increases in younger children.

Conclusions: Our results do not support that the level of expression of ACE2 and TMPRSS2 might be related to susceptibility or severity of COVID19 disease. Children have a decreased susceptibility to SARS-CoV-2 infection compared to adults and, when infected, they present less symptoms and a more benign course.

\section{Background}

Understanding the differences in disease susceptibility to the new severe acute respiratory syndrome coronavirus type 2 (SARS-CoV-2) and its variants is an ongoing quest. Recent collaborative studies are starting to shed light into the role the immune system plays in the susceptibility to severe COVID19 disease, showing that patients with an impaired type I IFN immunity are more susceptible to severe COVID19 disease[1-2]. Still, the reported defects only explain the increased susceptibility of a small percentage of the cases.

To initiate its infective cycle, SARS-CoV-2 uses the angiotensin-converting enzyme type 2 (ACE2) and type II transmembrane serine protease (TMPRSS2) present in the nasopharyngeal epithelium, among other tissues [3] (Image 1). Current studies have reported contradictory results regarding ACE2 expression, with some, but not all, showing that ACE2 expression is age and tissue-dependent, with a lower expression in children [4],[5].

On the basis of the transmission pattern observed in other respiratory viruses such as influenza, it was assumed that children could be important transmitters of SARS-CoV-2. However, published data point toward similar [6] or even lower [7],[8] infection rates in children than in adults. They are mainly infected from close relatives and experience milder symptoms [9],[10]. Age has been proven to be an important factor in the transmission of the virus [8], whereas the role of other factors, such as viral load, are still unclear [11] [12].

The study of specific antibodies against the virus plays an important role in understanding its epidemiology[13]. Almost all immunocompetent individuals develop detectable antiviral antibodies within 2 to 3 weeks after the onset of symptoms [14], although its protective capacity and durability are currently unknown [15].

Our objective was to deepen our understanding of the mechanisms that influence the infectious capacity of the virus through the analysis of the expressions of ACE2 and TMPRSS2 protease and its effect on the virus transmission dynamics in the population of the island of Gran Canaria (Canary Islands, Spain).

\section{Methods}

\section{Study population}

A total of 549 patients with infections confirmed via nasopharyngeal exudates by reverse-transcription polymerase chain reaction (RTPCR) in Gran Canaria from 10 March to 2 June 2020, as well as their household members, were included in this study.

The cases were identified from the epidemiological survey performed by the Canary Islands Health Service since the first case was detected in Gran Canaria in March 2020. Patients were diagnosed after presenting symptoms and having an epidemiological contact 
(travel to a high-risk area or close contact with a diagnosed patient). We attempted telephone contact with all the cases, regardless of the severity of the infection, and invited them to participate in the study, along with their household members. Participation was voluntary. All the participants signed written consent acknowledging their willingness to participate in the study (in the underaged population, the acceptance was signed by the legal guardian). The first diagnosed member of each family was considered the index case. Each of the family nuclei determined a cluster, with a total of 258 clusters participating in the study, for a total of 650 participants (0-89 years). Not all participants agreed to undertake serology testing. Figure 1 summarizes the number of participants.

Participants $\geq 18$ years of age were considered adults. Participants $<18$ years of age were considered pediatric cases.

\section{Data and sample collection}

Blood samples, saliva, and epidemiological survey data were collected from all the participants at the Complejo Hospitalario Universitario Insular Materno (CHUIMI) of Las Palmas de Gran Canaria in July 2020 after obtaining approval from the local ethics committee.

We assessed, among other variables, the age, sex, characteristics of the cluster (the house size, number of cohabitants, and cosleeping behavior), weight, body mass index (BMI), smoking habits, and presence of previously existing diseases.

\section{RT-PCR}

The molecular diagnosis of SARS-CoV-2 was performed by real-time RT-PCR in samples from nasopharyngeal swabs following the kit manufacturers' instructions. The targeted specific genes for SARS-CoV-2 included the nucleocapsid N gene, the RdRP gene of RNA polymerase (Allplex® 2019-nCoV Assay, Seegene, South Korea or LightMix® Modular SARS-CoV-2, Tib Molbiol, Germany), and the ORF1a / b fragment (cobas ${ }^{\circledR}$ SARS-CoV-2 test, Roche, Germany) encoding non-structural proteins for replication. The E gene for the envelope, typical of the Sarbecovirus subgenus, was used as a pan-Sarbecovirus marker.

\section{Serum IgG to SARS-CoV-2}

The serological analysis was performed by the Microbiology Department of Dr. Negrín University Hospital and CHUIMI Hospital. Initially, the presence of serum IgG antibodies to SARS-CoV-2 nucleocapsid protein was analyzed by an automated chemiluminescent microparticle enzyme immunoassay (SARS-CoV-2 IgG, ARCHITECT, Abbott Diagnostics). Following the manufacturer's technical instructions, any result with an index equal to or greater than 1.4 was interpreted as positive. As a strategy to increase the diagnostic sensitivity by recovering the antispike positives, in the samples with a negative result between 0.1 and 1.39 , the microbiological study was completed with the detection of IgG antibodies against spicule and nucleocapside proteins using an indirect chemiluminescent immunoassay (CLIA), interpreting an index of antibodies higher than 1.6 as positive (COVID-19 VIRCLIA IgG Monotest, Vircell).

\section{ACE2 and TMPRSS2 serine protease expression}

Total RNA was extracted from cells obtained from participants' saliva samples using TRIzol (Invitrogen), and cDNA was synthesized using the iScript kit (Biorad). Nasopharyngeal and saliva swabs of healthy controls $(\mathrm{N}=14)$ yielded RNAs with similar quantities and qualities (control test). ACE2 fragment amplification was performed via RT-PCR analysis, as previously described [16], with minor modifications. The expression level of TMPRSS2 was evaluated using the primers and conditions previously reported [17]. Since a very low expression level for the ACE2 gene was observed in saliva samples, a previous pre-amplification step was performed for this gene fragment. The relative expression levels of TMPRSS2 and ACE2 amplicons were determined by implementing the standard curve method. The cDNAs synthesized from pooled RNAs obtained from healthy controls were used as the reference to generate standard curves. The expression of the housekeeping $\beta$-actin gene was used for normalization.

\section{Statistical analysis}

We used R Core Team 2020, version 4.0.2, for statistical analysis. For descriptive statistics, we calculated the mean, standard deviation, median, and 25th and 75th percentiles for quantitative variables, and the frequency of appearance and percentage for the qualitative variables. The Kolmogorov-Smirnov test was used to check for normality. Student's $t$-test or the Mann-Whitney U-test were used to compare numerical variables between cohorts depending on the sample size and the normality of the data. Fisher's exact test was used to evaluate the dependence of qualitative variables and logistic regression to predict dichotomous variables. The area under the ROC curve was evaluated to check the validity of the model. Values with $p<0.05$ were considered statistically significant. 


\section{Results}

\section{Demographics}

Of the 242 index cases, 239 were adults and only 3 were below 18 years of age (aged 1, 12, and 15 years). Most cohabitants were also adults, with only 89 individuals younger than 18 years. Table 1 summarizes the participants' characteristics.

Table 1

Participants' characteristics.

\begin{tabular}{|c|c|c|c|}
\hline & & Index patients & Cohabitants \\
\hline Number of clusters & 258 & & \\
\hline Family members per household (mean (SD)) & $2.6(1.3)$ & & \\
\hline Clusters with children $<18$ years & 67 & & \\
\hline Total participants & 650 & $242^{\star}$ & 408 \\
\hline Mean age (years (SD)) & $44.7(21)$ & 54 & 39.5 \\
\hline Group age $<18$ years $(\mathrm{N}(\%))$ & $89(13.7 \%)$ & $3(1.2 \%)$ & $86(21 \%)$ \\
\hline Mean age (years (SD) & $8.8(5.3)$ & $9.3(7.3)$ & $8.8(5.3)$ \\
\hline Age range (years) & $0-17$ & $1-15$ & $0-17$ \\
\hline Group age $>18$ years $(\mathrm{N}(\%))$ & $561(86.3 \%)$ & $239(98.8 \%)$ & $322 / 79 \%)$ \\
\hline Mean age (years (SD) & $50.3(16.4)$ & 54 & 47 \\
\hline Age range & $18-89$ y & $20-87$ & $18-89$ \\
\hline $18-49$ years & 271 & 99 & 171 \\
\hline $50-65$ years & 163 & 71 & 92 \\
\hline$\geq 65$ years & 128 & 69 & 59 \\
\hline Female participants (\%) & 53.7 & 56 & 52.5 \\
\hline
\end{tabular}

\section{Source of infection}

The most common sources of infection were household transmission (38\%) and travel to high-incidence areas (30\%). Table 2 summarizes all reported sources of infection.

Table 2

Sources of infection.

\begin{tabular}{|lllllll|}
\hline $\begin{array}{l}\text { Source of infection } \\
(\mathbf{N}=\mathbf{X})\end{array}$ & Health worker & Essential worker & Travel & Cohabitants & Party & Other sources* \\
\hline$\%$ & 5.8 & 11.2 & 30.1 & 38 & 0.2 & 14.7 \\
\hline *Unspecified other sources of infection. & & & & \\
\hline
\end{tabular}

\section{Serologic results}

In our sample, 315 individuals (50.5\% of the sample) presented a positive antinucleocapsid IgG test. Among 103 participants with no IgG antibodies against nucleocapside, 68 presented an IgG antibody against the spike protein, thus increasing the seroprevalence in our sample from 50.5-61.4\%. Overall, a total of 383/623 participants who undertook serological testing of antibodies against SARSCoV-2 presented a positive result, resulting in a seroprevalence of $61.4 \%$ in our sample ( $42 \%$ if we exclude index cases) 
We found a significantly increased age in adult seropositive patients ( $53.5 \mathrm{vs.} 44.7$ years; $p<0.001$ ), as well as a significant younger age in seropositive children (10 vs. 7 years; $p=0.038$ ) (Fig. 2).

When examining the correlation between age and the antibody indexes, we found a significantly positive correlation for the nucleocapsid results in adults (Pearson's $r=0.44, p<0.001$ ), but not for the antispike results (Pearson's $r=0.4 ; p=0.89$ ), which persisted independently of the severity of infection (Table 3 ).

Table 3

Most common symptoms and frequency of appearance among IgG-positive patients.

\begin{tabular}{|lllll|}
\hline Symptom & $\begin{array}{l}\text { Frequency } \\
\text { (global) }\end{array}$ & Frequency (adults) & Frequency (children) & OR (p-value) \\
\hline Fever & $57,2 \%$ & $58,1 \%$ & $38,8 \%$ & $2.5(0.06)$ \\
\hline Cough* & $54.8 \%$ & $56,2 \%$ & $27,7 \%$ & $3.77(0.01)$ \\
\hline Anosmia* & $54.8 \%$ & $57,3 \%$ & $5,6 \%$ & $25.2(<0.001)$ \\
\hline Myalgia* & $52,7 \%$ & $54,8 \%$ & $11,1 \%$ & $10.6(<0.001)$ \\
\hline Diarrhea* & $42 \%$ & $43,6 \%$ & $11,1 \%$ & $4.2(0.018)$ \\
\hline Nasal discharge & $40,2 \%$ & $41,1 \%$ & $22,2 \%$ & $2.8(0.06)$ \\
\hline Difficulty breathing* & $36 \%$ & $37,8 \%$ & $0 \%$ & $1.9(0.3)$ \\
\hline Odynophagia & $32,6 \%$ & $33,2 \%$ & $22,2 \%$ & $1.7(0.5)$ \\
\hline Abdominal pain & $22,1 \%$ & $22,7 \%$ & $11,1 \%$ & $1.1(1)$ \\
\hline Cutaneous manifestations & $21,5 \%$ & $17,8 \%$ & $16,6 \%$ & $4.6(0.002)$ \\
\hline Vomiting & $12,5 \%$ & $13,2 \%$ & $0 \%$ & \\
\hline Asymptomatic* & $16.4 \%$ & $15 \%$ & $44.4 \%$ & \\
\hline *These symptoms presented significantly & more in adults than in children. & \\
\hline
\end{tabular}

In children, we found a nonsignificant negative correlation with age for the antinucleocapsid antibody indexes (Pearson's $r=-0.36, p=$ 0.11) (Fig. 3).

\section{Clinical characteristics}

Symptoms appeared in $83.6 \%$ of IgG-positive patients and $28 \%$ of IgG-negative patients. Children were more frequently asymptomatic than adults ( $44.4 \%$ vs. $15 \%$. OR: $4.6(95 \% \mathrm{Cl}=1.8-11.7)$; $\mathrm{p}<0.002)$. Among IgG-positive adult patients, fever was the most common symptom, followed by cough and anosmia. In children, cough and odynophagia were the most common. Table 4 summarizes the presenting symptoms. Asthenia and headache were also cited by patients among the most frequent symptoms under the classification of "other symptoms".

Table 4

Risk of acquiring SARS-CoV-2 infection in the household (children vs. adults).

\begin{tabular}{|llll|}
\hline & Positive serology & Negative serology & Total \\
\hline Children (not index case) & 19 & 55 & 74 \\
\hline Adults (not index case) & 144 & 169 & 313 \\
\hline Total & 163 & 224 & 387 \\
\hline OR: 0.56 (95\% Cl: $0.37-0.84) ; p=0.002$. & & \\
\hline
\end{tabular}

Adults presented with more severe symptoms. No children presented with pneumonia or were hospitalized in our sample, whereas 77 adults presented with pneumonia, 96 were hospitalized (24 required ICU admission), and 38 died (all aged >61 years). 
Regarding the dynamics of the transmission in the household, $54.4 \%$ of the participating families had a cohabitant other than the index case infected, and $7.6 \%$ of the families with children in the household presented at least one child with a positive IgG result for SARS-CoV-2.

In our sample, the factors facilitating SARS-CoV-2 transmission within the household were age ( $p=0.02 ;$ OR: $1.05 ; 95 \% \mathrm{Cl}$ : 1.02-1.08), and sharing the bedroom with an index case ( $p<0.01$; OR: 6.8; $95 \% \mathrm{Cl}$ : 2.8-17.6). We did not find a significant effect of sex, previous illnesses, house size, BMl, or smoking on increasing the risk of acquiring the disease.

The secondary attack rate among household contacts of index cases showed that children had almost half the risk of acquiring SARSCoV-2 infection of adults $(21.7 \%$ vs. $46 \% ; p=0.002)$. Table 5 summarizes the results. Due to the small number of pediatric index cases, we were not able to evaluate the rate at which children transmitted the disease in our population.

Table 5

Multivariable linear regression analysis.

\begin{tabular}{|lllll|}
\hline & B & Standard error & p-value & $95 \%$ Cl \\
\hline Constant & -0.09 & 0.53 & 0.86 & -1.13 to 0.94 \\
\hline No symptoms - No Hospitalization & Ref. & - & - & - \\
\hline Symptoms - No Hospitalization & 0.61 & 0.34 & 0.07 & -0.06 to 1.29 \\
\hline Symptoms - Hospitalization & 1.84 & 0.41 & $<0.001$ & $1.03-2.64$ \\
\hline Symptoms - ICU & 1.41 & 0.56 & 0.01 & $0.3-2.52$ \\
\hline Age & 0.07 & 0.01 & $<0.001$ & $0.005-0.08$ \\
\hline Concordance & & & & 0.67 \\
\hline
\end{tabular}

\section{ACE2 and TMPRSS2 expression}

We obtained valid samples for analysis of mRNA expression from 488 patients for ECA2 and 576 patients for TMPRSS2. Table 6 summarizes the characteristics of our sample.

Table 6

Characteristics of patients with ECA2 and TMPRSS2 expression.

\begin{tabular}{|c|c|c|c|c|c|c|c|c|c|}
\hline & $\begin{array}{l}\text { Adults } \\
(\mathrm{N})\end{array}$ & $\begin{array}{l}\text { Children } \\
(\mathrm{N})\end{array}$ & $\begin{array}{l}\text { Total } \\
(\mathrm{N})\end{array}$ & $\begin{array}{l}\text { Quantification (mean } \\
\text { (SD); median) }\end{array}$ & & $\begin{array}{l}\text { Adults } \\
(\mathrm{N})\end{array}$ & $\begin{array}{l}\text { Children } \\
(\mathrm{N})\end{array}$ & $\begin{array}{l}\text { Total } \\
(\mathrm{N})\end{array}$ & $\begin{array}{l}\text { Quantification } \\
\text { (mean (SD); } \\
\text { median) }\end{array}$ \\
\hline \multirow[t]{2}{*}{ ACE2 } & 444 & 44 & 488 & 198.9(537.8) & TMPRSS2 & 518 & 58 & 576 & 166.76 (528) \\
\hline & & & & 110.2 & & & & & 93.3 \\
\hline $\begin{array}{l}\text { IgG } \\
\text { positive }\end{array}$ & 271 & 10 & 281 & & $\begin{array}{l}\text { IgG } \\
\text { positive }\end{array}$ & 313 & 14 & 327 & \\
\hline $\begin{array}{l}\text { lgG } \\
\text { negative }\end{array}$ & 173 & 34 & 207 & & $\begin{array}{l}\text { IgG } \\
\text { negative }\end{array}$ & 205 & 44 & 249 & \\
\hline
\end{tabular}

After analysis, unexpectedly, we found a significantly small inverse correlation between ACE2 expression and age in the overall sample (Spearman's $r=-0.11, p=0.02$ ). When considering age groups, we found the correlation in children $<18$ years of age (Spearman's $r=$ $-0.34, p=0.035$ ), but not in adults (Spearman's $r=-0.03, p=0.53$ ) (Figs. 4a,b). Additionally, when analyzing factors that could be related to the expression, we found no significant correlation with BMI or antibody indexes. We also found no difference in expression when comparing medians by sex, smoking, positive serologic results, severity of symptoms (including hospitalization and ICU care), or previous disease (Table 7). The expression decreased in patients who presented with diarrhea (212 vs. 158, $p=0.025)$. 
Table 7

Correlation and median comparison. ACE2 and TMPRSS2 expression.

\begin{tabular}{|c|c|c|c|c|c|c|c|c|c|}
\hline & $\mathrm{BMI}^{\mathrm{a}}$ & $\begin{array}{l}\text { Antibody } \\
\text { indexes }^{\mathrm{a}}\end{array}$ & $\begin{array}{l}\text { Sexb } \\
\text { (male } \\
\text { vs. } \\
\text { female) }\end{array}$ & $\begin{array}{l}\text { Smoking } \\
\text { b (yes } \\
\text { vs. no) }\end{array}$ & $\begin{array}{l}\text { IgG anti- } \\
\text { N protein } \\
\text { b } \\
\text { (positive } \\
\text { vs. } \\
\text { negative) }\end{array}$ & $\begin{array}{l}\text { IgG anti- } \\
\text { S protein } \\
\text { b } \\
\text { (positive } \\
\text { vs. } \\
\text { negative) }\end{array}$ & $\begin{array}{l}\text { Hospitalization } \\
\text { b (yes vs. no) }\end{array}$ & $\begin{array}{l}\text { Hospitalized } \\
\text { in ICU b (yes } \\
\text { vs. no) }\end{array}$ & $\begin{array}{l}\text { Any } \\
\text { symptoms } \\
\text { b (yes vs. } \\
\text { no) }\end{array}$ \\
\hline TMPRSS22 & $\begin{array}{l}r= \\
0.01 ; \\
p= \\
0.88\end{array}$ & $\begin{array}{l}r=0.02 \\
p=0.66\end{array}$ & $\begin{array}{l}100 \text { vs. } \\
90 ; p= \\
0.128\end{array}$ & $\begin{array}{l}94 \text { vs. } \\
110 ; p= \\
0.54\end{array}$ & $\begin{array}{l}95 \text { vs. } \\
92 ; p= \\
0.6\end{array}$ & $\begin{array}{l}88 \text { vs. } \\
104 ; p= \\
0.15\end{array}$ & $\begin{array}{l}103 \text { vs. } 92 ; p= \\
0.16\end{array}$ & $\begin{array}{l}125 \text { vs. } 97 \\
p=0.12\end{array}$ & $\begin{array}{l}95 \text { vs } 92 \\
p=0.44\end{array}$ \\
\hline ECA2 & $\begin{array}{l}r= \\
-0.03 ; \\
p= \\
0.6\end{array}$ & $\begin{array}{l}r=-0.07 \\
p=0.16\end{array}$ & $\begin{array}{l}114 \text { vs. } \\
109 ; \mathrm{p} \\
=0.948\end{array}$ & $\begin{array}{l}112 \text { vs. } \\
110, p= \\
0.9\end{array}$ & $\begin{array}{l}108 \text { vs. } \\
117 ; p= \\
0.11\end{array}$ & $\begin{array}{l}116 \text { vs. } \\
112 ; p= \\
0.98\end{array}$ & $\begin{array}{l}107 \text { vs. } 113 ; p \\
=0.38\end{array}$ & $\begin{array}{l}93 \text { vs. } 111 \\
p=0.98\end{array}$ & $\begin{array}{l}109 \text { vs } \\
113 ; p= \\
0.27\end{array}$ \\
\hline
\end{tabular}

Regarding TMPRSS2 expression, we found no significant correlation with age (Fig. 4,b), BMI, or antibody indexes. We found no differences in expression when categorizing by sex, smoking, positive serologic results, the severity of symptoms (including hospitalization and ICU care), or previous disease (Table 7).

\section{Discussion}

One of the main goals of our study was to increase our ability to detect individuals who were infected by SARS-CoV-2 in our population. We hoped that the use of a combined serologic testing strategy would help increase our detection rate in order to improve our understanding of the SARS-CoV-2 virus and the role ACE2 and TMPRSS2 play in its transmission dynamics.

The seroprevalence in our sample was much higher (61.4\%) than that described by Pollán et al. [18] for Spain, mainly due to our sampling, which was not designed for evaluating the seroprevalence of the disease in our general population, and to participation bias, since those individuals who were more concerned about possible intrafamilial transmission were more likely to volunteer. Still, our use of two consecutive serologic tests increased our sensitivity by $10 \%$, highlighting the importance of the methodology used when trying to detect antibodies against SARS-CoV-2.

Regarding the secondary attack rate, reports provide a wide range of results. Maltezou et al. (60\%) [19] and Grijalva et al (53\%) [20] reported similar rates to ours. Wei et al. (16\%) and Wang et al. (30\%) reported smaller secondary attack rates in their studies in Wuhan [7],[21]. Madewell et al. [22] published a review of the papers studying the household transmission of SARS-CoV-2 in December 2020. Most studies only used RT-PCR for the diagnosis, thus probably underestimating the real spreading capacity of the SARS-CoV-2 virus in the household [23]. They found an overall secondary attack rate of $16.6 \%$, with variables such as the presence of symptoms, age, and the proximity to the index case (spouse) increasing the risk of transmission. Even though our attack rates differ, we report similar results regarding the effect of age and sharing the bedroom with index cases. We also found a decreased seroprevalence in children $(21.7 \%$ vs. $46 \%)$, with a significantly lower secondary attack rate (OR: $0.56,95 \% \mathrm{Cl}: 0.37-0.84)$. These findings are not new. Viner et al. reported a surprisingly similar result (OR: 0.56) in their meta-analysis after revising 32 studies including 41,640 children and adults [24]. Given the low number of pediatric index cases, we could not evaluate the risk of transmission from those of pediatric age. Other authors reported very low secondary attack rates from children [25], whereas Li et al recently reported children and adolescents to be more infectious than older adults [8].

In our sample, the effect of age on disease susceptibility was observed in both children and adults. IgG-positive children were significantly younger than IgG-negative patients (7 vs. 10 years of age), as was also reported by Li et al [8]. Closer contact with index cases was clearly related with an increased risk of infection. In our sample, this was demonstrated by the increased risk presented by cohabitants sharing the bedroom with an index case. Within the adult population, we also found a significant difference in age in seropositive patients, with an almost 10-year difference (53 vs. 44 years) between infected and noninfected individuals. In this case, older patients were at an increased risk, as reported in most studies. 
When considering the symptoms, it has been clearly established that children, especially those below ten years of age, present much milder forms of the disease [26]. In our sample, none of the children were hospitalized, had pneumonia, or presented with difficulty breathing. Furthermore, during the study period, none of the approximately 106,672 children under 14 years of age living in Gran Canaria [27] required hospitalization due to SARS-CoV-2 infection.

Regarding antibody indexes in children, Torres et al. [28] reported an association between younger age and positivity rates. We did not find such an association; however, we found a positive correlation between antibody indexes and age, with children presenting lower indexes than adults, and severity, with symptomatic and hospitalized patients presenting higher antibody indexes than asymptomatic patients. Klein et al. [29] also found an increased response in older patients and in those with a more severe form of the disease. They reported a correlation with sex that was not confirmed in our sample. Yonker et al. [12] reported similar results in children, with those affected with the more severe forms of the disease presenting an increased humoral response.

There is no proven explanation for the difference between children and adults or for the role played by an increased or decreased antibody index in SARS-CoV-2 infection. Some studies [30] suggested that the infection is less severe in children due to an attenuated immune response, which can result in tolerance to the virus [31]. Weisberg et al. [32] commented on the possibility that differences in the immune response between children and adults, with an increased anti-S(antispicule) response in children, might play a role in the decreased susceptibility to SARS-CoV-2 infection and severe COVID-19 reported in children. The decreased severity was also proposed to result from trained innate immunity conferred by live attenuated vaccines such as measles, mumps, and rubella [33]. In addition, ageing per se is associated with IFN-1 dysfunction, and immunity mediated by plasmacytoid dendritic cells decreases with age in adults[34].

Since the discovery that SARS-CoV-2 uses ACE2 as a gateway to the cell, many studies have tried to link its presence and degree of expression with different aspects related to the prognosis of patients. The publication of the first studies reporting a lower level of ACE2 expression in the upper respiratory tract of children compared with adults raised the possibility that it represents a protective factor against infection from SARS-CoV-2 virus and severe COVID-19 disease in children [4],[35],[36]. Other authors did not find this difference in expression, reporting similar levels when examining children's and adults ACE2 expression in the lungs [5]. However, these studies were performed in healthy individuals. Studies in SARS-CoV-2-infected patients are still scarce. Yonker et al. [12] studied ACE2 expression in infected and healthy children, reporting increased expression in children older than 10 years and in those who had been infected by SARS-CoV-2. In our series, we found a different gradient of expression, with slightly increased expression of ACE2 in children $<18$ years of age compared with adults, and increased expression in younger compared with older children. We found no differences in the expression between IgG-positive and -negative children or adults. No differences were either found in ACE2 expression related to BMI, smoking status, or severity of the disease. Notably, whereas Yonker et al obtained their samples from both naso- and oral swabs, we obtained our samples from saliva swabs. None of the other authors studying ACE2 expression obtained their samples from saliva.

Given the close interaction between ACE2 and other proteins expressed in the host cell's membranes required to facilitate virus entry, such as TMPRSS2 [3] and HAT [37], we decided to analyze the expression of TMPRSS2 and evaluate its possible role in the SARS-CoV2 infection cycle. We found no significant differences in expression with age, BMI, sex, infection, or severity of the disease. Thus, our findings do not support that levels of TMPRSS2 expression might be related to the severity of COVID-19 disease.

Conflicting findings complicate establishing the role of the quantitative expression of both ACE2 and TMPRSS2 in the susceptibility to and severity of SARS-CoV-2 infection. Perhaps it is not so much the amount of receptor and protease expressed in the cell's surface, but rather their functionality, which is probably linked to genetic polymorphisms, which account for the differential effect of the virus in the population [38].

The strengths of our study are: (1) the use of serology, testing both symptomatic and asymptomatic household members; (2) the combined use of two techniques targeting different antigens; (3) soon after the first case was declared, the island established lockdown, increasing the likelihood that transmission to household members was truly from the index case.

The limitations of our study are that, in the initial phases of the disease, the use of RT-PCR for the diagnosis of COVID-19 was limited to patients with an epidemiological link to COVID-19 and who presented clear symptoms of the disease (fever and respiratory symptoms). Thus, (1) asymptomatic patients and those without a clear epidemiological link were not diagnosed; (2) among those diagnosed, only half of the target population decided to participate in our study; (3) we assumed that the index case was the first 
symptomatic positive patient in the household, when, in truth, it could have been another household member; (4) the symptom recollection was subject to recall bias given the lag between the survey and the symptomatic period (1-4 months); (5) finally, we cannot guarantee that all the household members acquired the infection from a family member.

\section{Conclusions}

The use of a combined serologic analysis helps to increase the detection rate of past SARS-CoV-2 infections. We found an increased expression of ACE2 in younger children. Our results do not support that the level of expression of ACE2 and TMPRSS2 might be related to the severity of COVID-19. Children are less frequently infected by SARS-CoV-2 and present a milder form of the disease, with fewer symptoms and decreased severity. Regarding the transmission of the disease in the household, age and sharing the bedroom with an index case increase the risk of acquiring the infection. The risk in adults increases with age, whereas in children, it increases in younger children. Children are at a decreased risk (OR: 0.56) of acquiring the infection compared with adults.

\section{Abbreviations}

SARS-CoV-2. Severe acute respiratory syndrome coronavirus type 2

ACE2. Angiotensin-converting enzyme type 2

TMPRSS2. Type II transmembrane serine protease

RT-PCR. Reverse-transcription polymerase chain reaction

BMI. Body mass index

\section{Declarations}

\section{Authors contribution:}

$\mathrm{YN}$ is responsible for leading the project, fundraising, design, data collection and analysis and was a major contributor in writing the manuscript; JP and AM collaborated in the design of the study, data collection, and were major contributors in writing the manuscript; $\mathrm{AH}$ and $\mathrm{MH}$ are responsible for serologic analysis, collaboration in design and editing the final version; FR is responsible for collaborating in the design, editing the final version and leading the genetic analysis of ACE2 and TMPRSS2; LC is responsible for performing genetic analysis of ACE2 and TMPRSS2 and editing the final version; JG is responsible for leading data analysis, collaborating in the design and editing the final version of the manuscript; $C R$ is responsible for collaborating in the analysis and made major contributions to the final version of the manuscript; SP, VW, JQ, AM, MD, MA, AG, AR, ZE, EC, IM, EC, AR, IM, RM, MN, AB, IM, LP are responsible for collaborating in the design, data collection and editing the final version of the manuscript.

Funding: This research was funded by Fundación Disa, project number OA20/024. Santa Cruz de Tenerife, Canary Islands, Spain. 2020. The funders had no role in the design of the study; in the collection, analyses, or interpretation of data; in the writing of the manuscript, or in the decision to publish the results.

Competing Interest: The authors declare no competing interests.

Authors contributions: All authors whose names appear on the submission: 1) made substantial contributions to the conception or design of the work; or the acquisition, analysis, or interpretation of data; or the creation of new software used in the work; 2) drafted the work or revised it critically for important intellectual content; 3) approved the version to be published; and 4) agree to be accountable for all aspects of the work in ensuring that questions related to the accuracy or integrity of any part of the work are appropriately investigated and resolved.

Ethics approval and consent to participate: The study was conducted according to the guidelines of the Declaration of Helsinki, and approved by the Ethics Committee of Las Palmas University Hospital Dr. Negrín (protocol code 2020-253-1 COVID-19, approved on June 26th 2020). Informed consent was obtained from all subjects involved in the study. Written consent was obtained from a parent or guardian for participants under 16 years old.

Page $10 / 19$ 
Availability of data and materials: The datasets generated during and/or analyzed during the current study are not publicly available due to patient confidentiality, but are available from the corresponding author on reasonable request.

Consent for publication: Not applicable. No identifying images or other personal clinical details of participants are presented that compromise anonymity.

Regarding Image 1, I declare that the image has not been taken from another source and is under no copyright. It was drawn specifically for this study by the author, Anica Tengelmann Meyer, who has given her consent for its use in the current publication.

\section{References}

1. P. Bastard, L. B. Rosen, Q. Zhang, E. Michailidis, H. H. Hoffmann, Y. Zhang, K. Dorgham, Q. Philippot, J. Rosain, V. Béziat, J. Manry, E. Shaw, L. Haljasmägi, P. Peterson, L. Lorenzo, L. Bizien, S. Trouillet-Assant, K. Dobbs, A. A. de Jesus, A. Belot, A. Kallaste, E. Catherinot, Y. Tandjaoui-Lambiotte, J. Le Pen, G. Kerner, B. Bigio, Y. Seeleuthner, R. Yang, A. Bolze, A. N. Spaan, O. M. Delmonte, M. S. Abers, A. Aiuti, G. Casari, V. Lampasona, L. Piemonti, F. Ciceri, K. Bilguvar, R. P. Lifton, M. Vasse, D. M. Smadja, M. Migaud, J. Hadjadj, B. Terrier, D. Duffy, L. Quintana-Murci, D. van de Beek, L. Roussel, D. C. Vinh, S. Tangye, F. Haerynck, D. Dalmau, J. Martinez-Picado, P. Brodin, M. C. Nussenzweig, S. Boisson-Dupuis, C. Rodríguez-Gallego, G. Vogt, T. H. Mogensen, A. J. Oler, J. Gu, P. D. Burbelo, J. I. Cohen, A. Biondi, L. R. Bettini, M. DÁngio, P. Bonfanti, P. Rossignol, J. Mayaux, F. Rieux-Laucat, E. S. Husebye, F. Fusco, M. V. Ursini, L. Imberti, A. Sottini, S. Paghera, E. Quiros-Roldan, C. Rossi, R. Castagnoli, D. Montagna, A. Licari, G. L. Marseglia, X. Duval, J. Ghosn, J. S. Tsang, R. Goldbach-Mansky, K. Kisand, M. S. Lionakis, A. Puel, S. Y. Zhang, S. M. Holland, G. Gorochov, E. Jouanguy, C. M. Rice, A. Cobat, L. D. Notarangelo, L. Abel, H. C. Su, J. L. Casanova, A. A. Arias, B. Boisson, S. Boucherit, J. Bustamante, M. Chbihi, J. Chen, M. Chrabieh, T. Kochetkov, T. Le Voyer, D. Liu, Y. Nemirovskaya, M. Ogishi, D. Papandrea, C. Patissier, F. Rapaport, M. Roynard, N. Vladikine, M. Woollett, P. Zhang, A. Kashyap, L. Ding, M. Bosticardo, Q. Wang, S. Ochoa, H. Liu, S. D. Chauvin, M. Stack, G. Koroleva, N. Bansal, C. L. Dalgard, A. L. Snow, J. Abad, S. Aguilera-Albesa, O. M. Akcan, I. A. Darazam, J. C. Aldave, M. A. Ramos, S. A. Nadji, G. Alkan, J. Allardet-Servent, L. M. Allende, L. Alsina, M. A. Alyanakian, B. Amador-Borrero, Z. Amoura, A. Antolí, S. Arslan, S. Assant, T. Auguet, A. Azot, F. Bajolle, A. Baldolli, M. Ballester, H. B. Feldman, B. Barrou, A. Beurton, A. Bilbao, G. Blanchard-Rohner, I. Blanco, A. Blandinières, D. BlazquezGamero, M. Bloomfield, M. Bolivar-Prados, R. Borie, A. A. Bousfiha, C. Bouvattier, O. Boyarchuk, M. R. P. Bueno, J. Bustamante, J. J. C. Agra, S. Calimli, R. Capra, M. Carrabba, C. Casasnovas, M. Caseris, M. Castelle, F. Castelli, M. C. de Vera, M. V. Castro, E. Catherinot, M. Chalumeau, B. Charbit, M. P. Cheng, P. Clavé, B. Clotet, A. Codina, F. Colkesen, F. Colkesen, R. Colobran, C. Comarmond, A. G. Corsico, D. Dalmau, D. R. Darley, N. Dauby, S. Dauger, L. de Pontual, A. Dehban, G. Delplancq, A. Demoule, A. Di Sabatino, J. L. Diehl, S. Dobbelaere, S. Durand, W. Eldars, M. Elgamal, M. H. Elnagdy, M. Emiroglu, E. H. Erdeniz, S. E. Aytekin, R. Euvrard, R. Evcen, G. Fabio, L. Faivre, A. Falck, M. Fartoukh, M. Faure, M. F. Arquero, C. Flores, B. Francois, V. Fumadó, F. Fusco, B. G. Solis, P. Gaussem, J. Gil-Herrera, L. Gilardin, M. G. Alarcon, M. Girona-Alarcón, J. C. Goffard, F. Gok, R. González-Montelongo, A. Guerder, Y. Gul, S. N. Guner, M. Gut, J. Hadjadj, F. Haerynck, R. Halwani, L. Hammarström, N. Hatipoglu, E. Hernandez-Brito, M. S. Holanda-Peña, J. P. Horcajada, S. Hraiech, L. Humbert, A. D. Iglesias, A. Íñigo-Campos, M. Jamme, M. J. Arranz, I. Jordan, F. Kanat, H. Kapakli, I. Kara, A. Karbuz, K. K. Yasar, S. Keles, Y. K. Demirkol, A. Klocperk, Z. J. Król, P. Kuentz, Y. W. M. Kwan, J. C. Lagier, Y. L. Lau, F. Le Bourgeois, Y. S. Leo, R. L. Lopez, D. Leung, M. Levin, M. Levy, R. Lévy, Z. Li, A. Linglart, J. M. Lorenzo-Salazar, C. Louapre, C. Lubetzki, C. E. Luyt, D. C. Lye, D. Mansouri, M. Marjani, J. M. Pereira, A. Martin, D. M. Pueyo, J. Martinez-Picado, I. Marzana, A. Mathian, L. R. B. Matos, G. V. Matthews, J. Mayaux, J. L. Mège, I. Melki, J. F. Meritet, O. Metin, I. Meyts, M. Mezidi, I. Migeotte, M. Millereux, T. Mirault, C. Mircher, M. Mirsaeidi, A. M. Melián, A. M. Martinez, P. Morange, C. Mordacq, G. Morelle, S. Mouly, A. Muñoz-Barrera, C. Nafati, J. F. Neves, L. F. P. Ng, Y. N. Medina, E. N. Cuadros, J. Gonzalo Ocejo-Vinyals, Z. Orbak, M. Oualha, T. Özçelik, Q. P. Hammarström, C. Parizot, T. Pascreau, E. Paz-Artal, R. P. de Diego, A. Philippe, Q. Philippota, L. Planas-Serra, D. Ploin, J. Poissy, G. Poncelet, M. Pouletty, P. Quentric, D. Raoult, A. S. Rebillat, I. Reisli, P. Ricart, J. C. Richard, N. Rivet, J. G. Rivière, G. R. Blanch, C. Rodrigo, C. Rodriguez-Gallego, A. Rodríguez-Palmero, C. S. Romero, A. Rothenbuhler, F. Rozenberg, M. Y. R. del Prado, J. S. Riera, O. Sanchez, S. Sánchez-Ramón, A. Schluter, M. Schmidt, C. E. Schweitzer, F. Scolari, A. Sediva, L. M. Seijo, D. Sene, S. Senoglu, M. R. J. Seppänen, A. S. Ilovich, M. Shahrooei, D. Smadja, A. Sobh, X. S. Moreno, J. Solé-Violán, C. Soler, P. Soler-Palacín, Y. Stepanovskiy, A. Stoclin, F. Taccone, Y. Tandjaoui-Lambiottea, J. L. Taupin, S. J. Tavernier, B. Terrier, C. Thumerelle, G. Tomasoni, J. Toubiana, J. T. Alvarez, S. Trouillet-Assanta, J. Troya, A. Tucci, M. V. Ursini, Y. Uzunhan, P. Vabres, J. Valencia-Ramos, A. M. van Den Rym, I. Vandernoot, H. Vatansev, V. Vélez-Santamaria, S. Viel, C. Vilain, M. E. Vilaire, A. Vincent, G. Voiriot, F. Vuotto, A. Yosunkaya, B. E. Young, F. Yucel, F. Zannad, M. Zatz, A. Belota, G. Foti, G. Bellani, G. Citerio, E. Contro, A. Pesci, M. G. Valsecchi, M. Cazzaniga, C. Bole-Feysot, S. Lyonnet, C. Masson, P. Nitschke, A. Pouliet, Y. Schmitt, F. Tores, M. Zarhrate, L. Abela, C. Andrejak, F. Angoulvant, D. Bachelet, R. Basmaci, S. Behillil, M. Beluze, D. Benkerrou, K. Bhavsar, F. Bompart, L. Bouadma, M. Bouscambert, M. Caralp, M. Cervantes-Gonzalez, A. Chair, A. Coelho, C. Couffignal, S. Couffin-Cadiergues, E. D'ortenzio, C. da Silveira,

Page $11 / 19$ 
M. P. Debray, D. Deplanque, D. Descamps, M. Desvallées, A. Diallo, A. Diouf, C. Dorival, F. Dubos, X. Duval, P. Eloy, V. V. E. Enouf, H. Esperou, M. Esposito-Farese, M. Etienne, N. Ettalhaoui, N. Gault, A. Gaymard, J. Ghosn, T. Gigante, I. Gorenne, J. Guedj, A. Hoctin, I. Hoffmann, S. Jaafoura, O. Kafif, F. Kaguelidou, S. Kali, A. Khalil, C. Khan, C. Laouénan, S. Laribi, M. Le, Q. Le Hingrat, S. Le Mestre, H. Le Nagard, F. X. Lescure, Y. Lévy, C. Levy-Marchal, B. Lina, G. Lingas, J. C. Lucet, D. Malvy, M. Mambert, F. Mentré, N. Mercier, A. Meziane, H. Mouquet, J. Mullaert, N. Neant, M. Noret, J. Pages, A. Papadopoulos, C. Paul, N. Peiffer-Smadja, V. Petrov-Sanchez, G. Peytavin, O. Picone, O. Puéchal, M. Rosa-Calatrava, B. Rossignol, P. Rossignol, C. Roy, M. Schneider, C. Semaille, N. S. Mohammed, L. Tagherset, C. Tardivon, M. C. Tellier, F. Téoulé, O. Terrier, J. F. Timsit, T. Treoux, C. Tual, S. Tubiana, S. van der Werf, N. Vanel, A. Veislinger, B. Visseaux, A. Wiedemann, Y. Yazdanpanah, L. Abelc, A. Alcover, H. Aschard, K. Astrom, P. Bousso, P. Bruhns, A. Cumano, C. Demangel, L. Deriano, J. Di Santo, F. Dromer, G. Eberl, J. Enninga, J. Fellay, I. Gomperts-Boneca, M. Hasan, S. Hercberg, O. Lantz, H. Mouquet, E. Patin, S. Pellegrini, S. Pol, A. Rausell, L. Rogge, A. Sakuntabhai, O. Schwartz, B. Schwikowski, S. Shorte, F. Tangy, A. Toubert, M. Touvier, M. N. Ungeheuer, M. L. Albert, D. Duffy, L. Quintana-Murci, L. Alavoine, K. K. A. Amat, S. Behillil, J. Bielicki, P. Bruijning, C. Burdet, E. Caumes, C. Charpentier, B. Coignard, Y. Costa, S. Couffin-Cadiergues, F. Damond, A. Dechanet, C. Delmas, D. Descamps, X. Duval, J. L. Ecobichon, V. Enouf, H. Espérou, W. Frezouls, N. Houhou, E. Ilic-Habensus, O. Kafif, J. Kikoine, Q. Le Hingrat, D. Lebeaux, A. Leclercq, J. Lehacaut, S. Letrou, B. Lina, J. C. Lucet, D. Malvy, P. Manchon, M. Mandic, M. Meghadecha, J. Motiejunaite, M. Nouroudine, V. Piquard, A. Postolache, C. Quintin, J. Rexach, L. Roufai, Z. Terzian, M. Thy, S. Tubiana, S. van der Werf, V. Vignali, B. Visseaux, Y. Yazdanpanah, M. van Agtmael, A. G. Algera, F. van Baarle, D. Bax, M. Beudel, H. J. Bogaard, M. Bomers, L. Bos, M. Botta, J. de Brabander, G. Bree, M. C. Brouwer, S. de Bruin, M. Bugiani, E. Bulle, O. Chouchane, A. Cloherty, P. Elbers, L. Fleuren, S. Geerlings, B. Geerts, T. Geijtenbeek, A. Girbes, B. Goorhuis, M. P. Grobusch, F. Hafkamp, L. Hagens, J. Hamann, V. Harris, R. Hemke, S. M. Hermans, L. Heunks, M. W. Hollmann, J. Horn, J. W. Hovius, M. D. de Jong, R. Koning, N. van Mourik, J. Nellen, F. Paulus, E. Peters, T. van der Poll, B. Preckel, J. M. Prins, J. Raasveld, T. Reijnders, M. Schinkel, M. J. Schultz, A. Schuurman, K. Sigaloff, M. Smit, C. S. Stijnis, W. Stilma, C. Teunissen, P. Thoral, A. Tsonas, M. van der Valk, D. Veelo, A. P. J. Vlaar, H. de Vries, M. van Vugt, W. Joost Wiersinga, D. Wouters, A. H. Zwinderman, D. van de Beek, L. Abelb, A. Aiuti, S. Al Muhsen, F. Al-Mulla, M. S. Anderson, A. A. Arias, H. B. Feldman, D. Bogunovic, A. Bolze, A. Bondarenko, A. A. Bousfiha, P. Brodin, Y. Bryceson, C. D. Bustamante, M. Butte, S. Chakravorty, J. Christodoulou, E. Cirulli, A. Condino-Neto, M. A. Cooper, C. L. Dalgard, J. L. DeRisi, M. Desai, B. A. Drolet, S. Espinosa, J. Fellay, C. Flores, J. L. Franco, P. K. Gregersen, F. Haerynck, D. Hagin, R. Halwani, J. Heath, S. E. Henrickson, E. Hsieh, K. Imai, Y. Itan, T. Karamitros, K. Kisanda, C. L. Ku, Y. L. Lau, Y. Ling, C. L. Lucas, T. Maniatis, D. Mansouri, L. Marodi, J. D. Milner, K. Mironska, T. Morio, L. D. Notarangeloa, G. Novelli, A. Novelli, C. O’Farrelly, S. Okada, T. Ozcelik, R. P. de Diego, A. M. Planas, C. Prando, A. Pujol, L. Quintana-Murci, L. Renia, A. Renieri, C. Rodríguez-Gallego, V. Sancho-Shimizu, V. Sankaran, K. S. Barrett, M. Shahrooei, A. Snow, P. Soler-Palacín, A. N. Spaan, S. Turvey, F. Uddin, M. J. Uddin, D. van de Beek, S. E. Vazquez, D. C. Vinh, H. von Bernuth, N. Washington, P. Zawadzki, H. C. Sua, \& J. L. Casanovaa, Autoantibodies against type I IFNs in patients with life-threatening COVID-19. Science, 370 (2020). https://doi.org/10.1126/science.abd4585.

2. Q. Zhang, Z. Liu, M. Moncada-Velez, J. Chen, M. Ogishi, B. Bigio, R. Yang, A. A. Arias, Q. Zhou, J. E. Han, A. C. Ugurbil, P. Zhang, F. Rapaport, J. Li, A. N. Spaan, B. Boisson, S. Boisson-Dupuis, J. Bustamante, A. Puel, M. J. Ciancanelli, S. Y. Zhang, V. Béziat, E. Jouanguy, L. Abel, A. Cobat, J. L. Casanova, P. Bastard, C. Korol, J. Rosain, Q. Philippot, M. Chbihi, L. Lorenzo, L. Bizien, A. L. Neehus, G. Kerner, Y. Seeleuthner, J. Manry, T. Le Voyer, B. Boisson, S. Boisson-Dupuis, J. Bustamante, A. Puel, S. Y. Zhang, V. Béziat, E. Jouanguy, L. Abel, A. Cobat, P. Bastard, J. Rosain, Q. Philippot, M. Chbihi, L. Lorenzo, L. Bizien, A. L. Neehus, G. Kerner, Y. Seeleuthner, J. Manry, T. Le Voyer, B. Boisson, S. Boisson-Dupuis, J. Bustamante, A. Puel, S. Y. Zhang, V. Béziat, E. Jouanguy, L. Abel, A. Cobat, J. Le Pen, W. M. Schneider, B. S. Razooky, H. H. Hoffmann, E. Michailidis, C. M. Rice, I. K. D. Sabli, S. Hodeib, V. Sancho-Shimizu, K. Bilguvar, J. Ye, T. Maniatis, A. Bolze, A. A. Arias, A. A. Arias, Y. Zhang, L. D. Notarangelo, H. C. Su, Y. Zhang, L. D. Notarangelo, H. C. Su, F. Onodi, S. Korniotis, L. Karpf, V. Soumelis, L. Bonnet-Madin, A. Amara, K. Dorgham, G. Gorochov, N. Smith, D. Duffy, L. Moens, I. Meyts, P. Meade, A. García-Sastre, F. Krammer, A. Corneau, C. Masson, Y. Schmitt, A. Schlüter, A. Pujol, T. Khan, N. Marr, J. Fellay, J. Fellay, J. Fellay, L. Roussel, D. C. Vinh, M. Shahrooei, M. Shahrooei, M. F. Alosaimi, F. Alsohime, R. Hasanato, D. Mansouri, D. Mansouri, D. Mansouri, H. AlSaud, F. Almourfi, F. Al-Mulla, S. Z. Al-Muhsen, S. Al Turki, S. Al Turki, D. van de Beek, A. Biondi, L. R. Bettini, M. D’Angio, P. Bonfanti, L. Imberti, A. Sottini, S. Paghera, E. Quiros-Roldan, C. Rossi, A. J. Oler, M. F. Tompkins, C. Alba, C. L. Dalgard, I. Vandernoot, G. Smits, J. C. Goffard, I. Migeotte, F. Haerynck, P. Soler-Palacin, A. Martin-Nalda, R. Colobran, P. E. Morange, S. Keles, F. Çölkesen, T. Ozcelik, K. K. Yasar, S. Senoglu, Ş. N. Karabela, C. Rodríguez-Gallego, C. Rodríguez-Gallego, G. Novelli, S. Hraiech, Y. Tandjaoui-Lambiotte, Y. Tandjaoui-Lambiotte, X. Duval, C. Laouénan, X. Duval, C. Laouénan, C. Laouénan, A. L. Snow, C. L. Dalgard, J. D. Milner, T. H. Mogensen, A. N. Spaan, J. Bustamante, M. J. Ciancanelli, T. Maniatis, V. Soumelis, M. Nussenzweig, M. Nussenzweig, A. García-Sastre, A. García-Sastre, A. García-Sastre, R. P. Lifton, R. P. Lifton, R. P. Lifton, G. Foti, G. Bellani, G. Citerio, E. Contro, A. Pesci, M. G. Valsecchi, M. Cazzaniga, J. Abad, I. Blanco, C. Rodrigo, S. Aguilera-Albesa, O. M. Akcan, I. A. Darazam, J. C. Aldave, M. A. Ramos, S. A. Nadji, G. 
Alkan, J. Allardet-Servent, L. M. Allende, L. Alsina, M. A. Alyanakian, B. Amador-Borrero, S. Mouly, D. Sene, Z. Amoura, A. Mathian, A. Antolí, G. R. Blanch, J. S. Riera, X. S. Moreno, S. Arslan, S. Assant, T. Auguet, A. Azot, F. Bajolle, J. Bustamante, R. Lévy, M. Oualha, A. Baldolli, M. Ballester, H. B. Feldman, B. Barrou, A. Beurton, A. Bilbao, G. Blanchard-Rohner, A. Blandinières, N. Rivet, D. BlazquezGamero, M. Bloomfield, M. Bolivar-Prados, P. Clavé, R. Borie, C. Bosteels, B. N. Lambrecht, E. van Braeckel, A. A. Bousfiha, C. Bouvattier, A. Vincent, O. Boyarchuk, M. R. P. Bueno, M. V. Castro, L. R. B. Matos, M. Zatz, J. J. C. Agra, S. Calimli, R. Capra, M. Carrabba, G. Fabio, C. Casasnovas, V. Vélez-Santamaria, M. Caseris, A. Falck, G. Poncelet, M. Castelle, F. Castelli, M. C. de Vera, E. Catherinot, M. Chalumeau, J. Toubiana, B. Charbit, Z. Li, S. Pellegrini, M. P. Cheng, B. Clotet, A. Codina, F. Colkesen, F. Çölkesen, R. Colobran, C. Comarmond, D. Dalmau, D. Dalmau, D. R. Darley, N. Dauby, S. Dauger, F. Le Bourgeois, M. Levy, L. de Pontual, A. Dehban, G. Delplancq, A. Demoule, J. L. Diehl, S. Dobbelaere, S. Durand, C. Mircher, A. S. Rebillat, M. E. Vilaire, W. Eldars, M. Elgamal, M. H. Elnagdy, M. Emiroglu, E. H. Erdeniz, S. E. Aytekin, R. Euvrard, R. Evcen, L. Faivre, M. Fartoukh, Q. Philippot, M. Faure, M. F. Arquero, C. Flores, C. Flores, C. Flores, C. Flores, B. Francois, V. Fumadó, V. Fumadó, V. Fumadó, F. Fusco, M. V. Ursini, B. G. Solis, R. P. de Diego, A. M. van Den Rym, P. Gaussem, J. Gil-Herrera, L. Gilardin, M. G. Alarcon, M. Girona-Alarcón, J. C. Goffard, F. Gok, A. Yosunkaya, R. GonzálezMontelongo, A. Íñigo-Campos, J. M. Lorenzo-Salazar, A. Muñoz-Barrera, A. Guerder, Y. Gul, S. N. Guner, M. Gut, J. Hadjadj, F. Haerynck, R. Halwani, L. Hammarström, N. Hatipoglu, E. Hernandez-Brito, C. Heijmans, M. S. Holanda-Peña, J. P. Horcajada, L. Hoste, E. Hoste, S. Hraiech, L. Humbert, C. Mordacq, C. Thumerelle, F. Vuotto, A. D. Iglesias, M. Jamme, M. J. Arranz, I. Jordan, P. Jorens, F. Kanat, H. Kapakli, I. Kara, A. Karbuz, K. K. Yasar, S. Senoglu, S. Keles, Y. K. Demirkol, A. Klocperk, Z. J. Król, P. Kuentz, Y. W. M. Kwan, J. C. Lagier, Y. L. Lau, D. Leung, Y. S. Leo, B. E. Young, R. L. Lopez, M. Levin, A. Linglart, B. Loeys, C. Louapre, C. Lubetzki, C. E. Luyt, D. C. Lye, D. Mansouri, M. Marjani, J. M. Pereira, A. Martin, P. Soler-Palacín, D. M. Pueyo, J. Martinez-Picado, I. Marzana, G. V. Matthews, J. Mayaux, C. Parizot, P. Quentric, J. L. Mège, D. Raoult, I. Melki, J. F. Meritet, O. Metin, M. Mezidi, I. Migeotte, F. Taccone, M. Millereux, T. Mirault, M. Mirsaeidi, A. M. Melián, A. M. Martinez, P. Morange, G. Morelle, L. Naesens, C. Nafati, J. F. Neves, L. F. P. Ng, Y. N. Medina, E. N. Cuadros, J. Gonzalo Ocejo-Vinyals, Z. Orbak, T. Özçelik, Q. Pan-Hammarström, T. Pascreau, E. Paz-Artal, A. Philippe, L. Planas-Serra, A. Schluter, D. Ploin, S. Viel, J. Poissy, M. Pouletty, I. Reisli, P. Ricart, J. C. Richard, J. G. Rivière, C. Rodriguez-Gallego, C. Rodriguez-Gallego, A. Rodríguez-Palmero, C. S. Romero, A. Rothenbuhler, F. Rozenberg, M. Y. R. del Prado, O. Sanchez, S. Sánchez-Ramón, M. Schmidt, C. E. Schweitzer, F. Scolari, A. Sediva, L. M. Seijo, M. R. J. Seppänen, A. S. Ilovich, H. Slabbynck, D. M. Smadja, A. Sobh, J. Solé-Violán, C. Soler, Y. Stepanovskiy, A. Stoclin, Y. Tandjaoui-Lambiotte, J. L. Taupin, S. J. Tavernier, B. Terrier, G. Tomasoni, J. T. Alvarez, S. TrouilletAssant, J. Troya, A. Tucci, Y. Uzunhan, P. Vabres, J. Valencia-Ramos, S. van de Velde, J. van Praet, I. Vandernoot, H. Vatansev, C. Vilain, G. Voiriot, F. Yucel, F. Zannad, A. Belot, C. Bole-Feysot, S. Lyonnet, C. Masson, P. Nitschke, A. Pouliet, Y. Schmitt, F. Tores, M. Zarhrate, M. Shahrooei, L. Abel, C. Andrejak, F. Angoulvant, D. Bachelet, K. Bhavsar, L. Bouadma, A. Chair, C. Couffignal, C. Da Silveira, M. P. Debray, X. Duval, P. Eloy, M. Esposito-Farese, N. Ettalhaoui, N. Gault, J. Ghosn, I. Gorenne, I. Hoffmann, O. Kafif, S. Kali, A. Khalil, C. Laouénan, S. Laribi, M. Le, Q. Le Hingrat, F. X. Lescure, J. C. Lucet, F. Mentré, J. Mullaert, N. Peiffer-Smadja, G. Peytavin, C. Roy, M. Schneider, N. S. Mohammed, L. Tagherset, C. Tardivon, M. C. Tellier, J. F. Timsit, T. Trioux, S. Tubiana, R. Basmaci, S. Behillil, M. Beluze, D. Benkerrou, C. Dorival, A. Meziane, F. Téoulé, F. Bompart, M. Bouscambert, A. Gaymard, B. Lina, M. Rosa-Calatrava, O. Terrier, M. Caralp, M. CervantesGonzalez, E. D’Ortenzio, O. Puéchal, C. Semaille, A. Coelho, A. Diouf, A. Hoctin, M. Mambert, S. Couffin-Cadiergues, D. Deplanque, D. Descamps, B. Visseaux, M. Desvallées, C. Khan, A. Diallo, N. Mercier, C. Paul, V. Petrov-Sanchez, F. Dubos, V. V. E. Enouf, H. Mouquet, H. Esperou, S. Jaafoura, A. Papadopoulos, M. Etienne, T. Gigante, B. Rossignol, J. Guedj, H. Le Nagard, G. Lingas, N. Neant, F. Kaguelidou, Y. Lévy, A. Wiedemann, Y. Lévy, A. Wiedemann, C. Levy-Marchal, D. Malvy, M. Noret, J. Pages, O. Picone, P. Rossignol, C. Tual, A. Veislinger, S. van der Werf, N. Vanel, Y. Yazdanpanah, L. Alavoine, Y. Costa, X. Duval, J. L. Ecobichon, W. Frezouls, E. Ilic-Habensus, A. Leclercq, J. Lehacaut, S. Letrou, M. Mandic, M. Nouroudine, C. Quintin, J. Rexach, S. Tubiana, V. Vignali, K. K. A. Amat, S. Behillil, V. Enouf, S. van der Werf, J. Bielicki, P. Bruijning, C. Burdet, C. Burdet, E. Caumes, C. Charpentier, F. Damond, D. Descamps, Q. Le Hingrat, B. Visseaux, B. Coignard, S. Couffin-Cadiergues, C. Delmas, H. Espérou, L. Roufai, A. Dechanet, N. Houhou, O. Kafif, J. Kikoine, P. Manchon, V. Piquard, A. Postolache, Z. Terzian, D. Lebeaux, B. Lina, J. C. Lucet, D. Malvy, M. Meghadecha, J. Motiejunaite, M. Thy, M. van Agtmael, M. Bomers, O. Chouchane, S. Geerlings, B. Goorhuis, M. P. Grobusch, V. Harris, S. M. Hermans, J. W. Hovius, J. Nellen, E. Peters, T. van der Poll, J. M. Prins, T. Reijnders, M. Schinkel, K. Sigaloff, C. S. Stijnis, M. van der Valk, M. van Vugt, W. Joost Wiersinga, A. G. Algera, F. van Baarle, L. Bos, M. Botta, S. de Bruin, E. Bulle, P. Elbers, L. Fleuren, A. Girbes, L. Hagens, L. Heunks, J. Horn, N. van Mourik, F. Paulus, J. Raasveld, M. J. Schultz, M. Smit, W. Stilma, P. Thoral, A. Tsonas, H. de Vries, D. Bax, A. Cloherty, M. Beudel, M. C. Brouwer, R. Koning, D. van de Beek, H. J. Bogaard, J. de Brabander, G. de Bree, M. Bugiani, B. Geerts, M. W. Hollmann, B. Preckel, D. Veelo, T. Geijtenbeek, F. Hafkamp, J. Hamann, R. Hemke, M. D. de Jong, A. Schuurman, C. Teunissen, A. P. J. Vlaar, D. Wouters, A. H. Zwinderman, L. Abel, A. Aiuti, S. Al Muhsen, F. Al-Mulla, M. S. Anderson, A. A. Arias, H. B. Feldman, D. Bogunovic, Y. Itan, A. Bolze, E. Cirulli, K. S. Barrett, N. Washington, A. Bondarenko, A. A. Bousfiha, P. Brodin, Y. Bryceson, C. D. Bustamante, M. Butte, G. Casari, S. Chakravorty, J. Christodoulou, S. Le Mestre, A. Condino-Neto, M. A. Cooper, C. L. Dalgard, A. David, J. L. DeRisi, J. L. DeRisi, M. Desai, B. A. Drolet, S. Espinosa, J. Fellay, C. Flores, J. L. Franco, P. K. Gregersen, F. Haerynck, D. Hagin, R. Halwani, J. Heath, S. E. Henrickson, E.

Page 13/19 
Hsieh, K. Imai, T. Karamitros, K. Kisand, C. L. Ku, Y. L. Lau, Y. Ling, C. L. Lucas, T. Maniatis, D. Mansouri, L. Marodi, J. Milner, K. Mironska, T. Morio, L. D. Notarangelo, H. C. Su, A. Novelli, G. Novelli, C. O’Farrelly, S. Okada, T. Ozcelik, R. P. de Diego, A. M. Planas, C. Prando, A. Pujol, L. Quintana-Murci, L. Renia, A. Renieri, C. Rodríguez-Gallego, V. Sancho-Shimizu, V. Sankaran, M. Shahrooei, A. Snow, P. Soler-Palacín, A. N. Spaan, S. Tangye, S. Turvey, F. Uddin, M. J. Uddin, M. J. Uddin, D. van de Beek, S. E. Vazquez, D. C. Vinh, H. von Bernuth, P. Zawadzki, H. Jing, W. Tung, K. Meguro, E. Shaw, H. Jing, W. Tung, S. Shafer, L. Zheng, Z. Zhang, S. Kubo, S. D. Chauvin, K. Meguro, E. Shaw, M. Lenardo, C. R. Luthers, B. M. Bauman, S. Shafer, L. Zheng, Z. Zhang, S. Kubo, S. D. Chauvin, M. Lenardo, J. Lack, E. Karlins, D. M. Hupalo, J. Rosenberger, G. Sukumar, M. D. Wilkerson, \& X. Zhang, Inborn errors of type I IFN immunity in patients with life-threatening COVID-19. Science, 370 (2020). https://doi.org/10.1126/science.abd4570.

3. M. Hoffmann, H. Kleine-Weber, S. Schroeder, N. Krüger, T. Herrler, S. Erichsen, T. S. Schiergens, G. Herrler, N. H. Wu, A. Nitsche, M. A. Müller, C. Drosten, \& S. Pöhlmann, SARS-CoV-2 Cell Entry Depends on ACE2 and TMPRSS2 and Is Blocked by a Clinically Proven Protease Inhibitor. Cell, 181 (2020) 271-280.e8. https://doi.org/10.1016/j.cell.2020.02.052.

4. S. Bunyavanich, A. Do, \& A. Vicencio, Nasal Gene Expression of Angiotensin-Converting Enzyme 2 in Children and Adults. JAMA Journal of the American Medical Association, 323 (2020) 2427-2429. https://doi.org/10.1001/jama.2020.8707.

5. Y. Tao, R. Yang, C. Wen, J. Fan, J. Ma, Q. He, Z. Zhao, X. Song, H. Chen, G. Shi, M. Yin, N. Fang, H. Zhang, H. Chen, \& X. Mo, SARSCoV-2 entry related genes are comparably expressed in children's lung as adults. medRxiv, (2020) 2020.05.25.20110890.

6. W. G. Qifang Bi*, Yongsheng Wu*, Shujiang Mei*, Chenfei Ye*, Xuan Zou, Zhen Zhang, Xiaojian Liu, Lan Wei, Shaun A Truelove, Tong Zhang \& T. F. Cong Cheng, Xiujuan Tang, Xiaoliang Wu, Yu Wu, Binbin Sun, Suli Huang, Yu Sun, Juncen Zhang, Ting Ma*, Justin Lessler*, Epidemiology and transmission of COVID-19 in 391 cases and 1286 of their close contacts in Shenzhen, China: a retrospective cohort study. Lancet infectious diseases, 20 (2020) 911-919. https://doi.org/10.1016/S1473-3099(20)30287-5.

7. W. Li, B. Zhang, J. Lu, S. Liu, Z. Chang, C. Peng, X. Liu, P. Zhang, Y. Ling, K. Tao, \& J. Chen, Characteristics of Household Transmission of COVID-19. Clinical Infectious Diseases, 71 (2020) 1943-1946. https://doi.org/10.1093/cid/ciaa450.

8. F. Li, Y.-Y. Li, M.-J. Liu, L.-Q. Fang, N. E. Dean, G. W. K. Wong, X.-B. Yang, I. Longini, M. E. Halloran, H.-J. Wang, P.-L. Liu, Y.-H. Pang, Y.Q. Yan, S. Liu, W. Xia, X.-X. Lu, Q. Liu, Y. Yang, \& S.-Q. Xu, Household transmission of SARS-CoV-2 and risk factors for susceptibility and infectivity in Wuhan: a retrospective observational study. The Lancet Infectious Diseases, 21 (2021) 617-628.

https://doi.org/10.1016/s1473-3099(20)30981-6.

9. R. Castagnoli, M. Votto, A. Licari, I. Brambilla, R. Bruno, S. Perlini, F. Rovida, F. Baldanti, \& G. L. Marseglia, Severe Acute Respiratory Syndrome Coronavirus 2 (SARS-CoV-2) Infection in Children and Adolescents. JAMA Pediatrics, 174 (2020) $882-889$.

https://doi.org/10.1001/jamapediatrics.2020.1467.

10. J. F. Ludvigsson, Systematic review of COVID-19 in children shows milder cases and a better prognosis than adults. Acta Paediatrica, International Journal of Paediatrics, 109 (2020) 1088-1095. https://doi.org/10.1111/apa.15270.

11. Taylor Heald-Sargent, William J. Muller, Xiaotian Zheng, Jason Rippe, Ami B. Patel, Larry K. Kociolek, Age-Related Differences in Nasopharyngeal Severe Acute Respiratory Syndrome Coronavirus 2 (SARS-CoV-2) Levels in PatientsWith Mild to Moderate Coronavirus Disease 2019 (COVID-19). JAMA Pediatrics, 174 (2020) 326-902-903. https://doi.org/10.1001/jamapediatrics.2020.3651.

12. L. M. Yonker, A. M. Neilan, Y. Bartsch, A. B. Patel, J. Regan, P. Arya, E. Gootkind, G. Park, M. Hardcastle, A. St. John, L. Appleman, M. L. Chiu, A. Fialkowski, D. De la Flor, R. Lima, E. A. Bordt, L. J. Yockey, P. D’Avino, S. Fischinger, J. E. Shui, P. H. Lerou, J. V. Bonventre, X. G. Yu, E. T. Ryan, I. V. Bassett, D. Irimia, A. G. Edlow, G. Alter, J. Z. Li, \& A. Fasano, Pediatric Severe Acute Respiratory Syndrome Coronavirus 2 (SARS-CoV-2): Clinical Presentation, Infectivity, and Immune Responses. Journal of Pediatrics, 227 (2020) $45-52 . e 5$. https://doi.org/10.1016/j.jpeds.2020.08.037.

13. C. Lai, J. Wang, \& P. Hsueh, Population-based seroprevalence surveys of anti-SARS-CoV-2 antibody: An up-to-date review. Int J Infect Dis, 101 (2020) 314-322. https://doi.org/10.1016/j.ijid.2020.10.011.

14. J. Zhao, Q. Yuan, H. Wang, W. Liu, X. Liao, Y. Su, X. Wang, J. Yuan, T. Li, J. Li, S. Qian, C. Hong, F. Wang, Y. Liu, Z. Wang, Q. He, Z. Li, B. He, T. Zhang, Y. Fu, S. Ge, L. Liu, J. Zhang, N. Xia, \& Z. Zhang, Antibody Responses to SARS-CoV-2 in Patients with Novel Coronavirus Disease 2019. Clinical Infectious Diseases, 71 (2020) 2027-2034. https://doi.org/10.1093/cid/ciaa344.

Page 14/19 
15. CDC. lab resources. Antibody test guideline. (n.d.).

16. J. F. Burgueno, A. Reich, H. Hazime, M. A. Quintero, I. Fernandez, J. Fritsch, A. M. Santander, N. Brito, O. M. Damas, A. Deshpande, D. H. Kerman, L. Zhang, Z. Gao, Y. Ban, L. Wang, J. Pignac-Kobinger, \& M. T. Abreu, Expression of SARS-CoV-2 entry molecules ACE2 and TMPRSS2 in the gut of patients with IBD. Inflammatory Bowel Diseases, 26 (2020) 797-808. https://doi.org/10.1093/ibd/izaa085.

17. D. Ma, C. B. Chen, V. Jhanji, C. Xu, X. L. Yuan, J. J. Liang, Y. Huang, L. P. Cen, \& T. K. Ng, Expression of SARS-CoV-2 receptor ACE2 and TMPRSS2 in human primary conjunctival and pterygium cell lines and in mouse cornea. Eye (Basingstoke), 34 (2020) 12121219. https://doi.org/10.1038/s41433-020-0939-4.

18. M. Pollán, B. Pérez-Gómez, R. Pastor-Barriuso, J. Oteo, M. A. Hernán, M. Pérez-Olmeda, J. L. Sanmartín, A. Fernández-García, I. Cruz, N. Fernández de Larrea, M. Molina, F. Rodríguez-Cabrera, M. Martín, P. Merino-Amador, J. León Paniagua, J. F. Muñoz-Montalvo, F. Blanco, R. Yotti, R. Gutiérrez Fernández, S. Mezcua Navarro, J. F. Muñoz-Montalvo, M. Salinero Hernández, J. L. Sanmartín, M. CuencaEstrella, J. León Paniagua, P. Fernández-Navarro, A. Avellón, G. Fedele, J. Oteo Iglesias, M. T. Pérez Olmeda, M. E. Fernandez Martinez, F. D. Rodríguez-Cabrera, M. A. Hernán, S. Padrones Fernández, J. M. Rumbao Aguirre, J. M. Navarro Marí, B. Palop Borrás, A. B. Pérez Jiménez, M. Rodríguez-Iglesias, A. M. Calvo Gascón, M. L. Lou Alcaine, I. Donate Suárez, O. Suárez Álvarez, M. Rodríguez Pérez, M. Cases Sanchís, C. J. Villafáfila Gomila, L. Carbo Saladrigas, A. Hurtado Fernández, A. Oliver, E. Castro Feliciano, M. N. González Quintana, J. M. Barrasa Fernández, M. A. Hernández Betancor, M. Hernández Febles, L. Martín Martín, L. M. López López, T. Ugarte Miota, I. De Benito Población, M. S. Celada Pérez, M. N. Vallés Fernández, T. Maté Enríquez, M. Villa Arranz, M. Domínguez-Gil González, I. Fernández-Natal, G. Megías Lobón, J. L. Muñoz Bellido, P. Ciruela, A. Mas i Casals, M. Doladé Botías, M. A. Marcos Maeso, D. Pérez del Campo, A. Félix de Castro, R. Limón Ramírez, M. F. Elías Retamosa, M. Rubio González, M. S. Blanco Lobeiras, A. Fuentes Losada, A. Aguilera, G. Bou, Y. Caro, N. Marauri, L. M. Soria Blanco, I. del Cura González, M. Hernández Pascual, R. Alonso Fernández, N. Cabrera Castro, A. Tomás Lizcano, C. Ramírez Almagro, M. Segovia Hernández, N. Ascunce Elizaga, M. Ederra Sanz, C. Ezpeleta Baquedano, A. Bustinduy Bascaran, S. Iglesias Tamayo, L. Elorduy Otazua, R. Benarroch Benarroch, J. Lopera Flores, \& A. Vázquez de la Villa, Prevalence of SARS-CoV-2 in Spain (ENE-COVID): a nationwide, population-based seroepidemiological study. The Lancet, 396 (2020) 535-544. https://doi.org/10.1016/S0140-6736(20)31483-5.

19. H. C. Maltezou, R. Vorou, K. Papadima, A. Kossyvakis, N. Spanakis, G. Gioula, M. Exindari, S. Metallidis, A. N. Lourida, V. Raftopoulos, E. Froukala, B. Martinez-Gonzalez, A. Mitsianis, E. Roilides, A. Mentis, A. Tsakris, \& A. Papa, Transmission dynamics of SARS-CoV-2 within families with children in Greece: A study of 23 clusters. Journal of Medical Virology, 93 (2021) 1414-1420. https://doi.org/10.1002/jmv.26394.

20. C. G. Grijalva, M. A. Rolfes, Y. Zhu, H. Q. McLean, K. E. Hanson, E. A. Belongia, N. B. Halasa, A. Kim, C. Reed, A. M. Fry, \& H. K. Talbot, Transmission of SARS-COV-2 Infections in Households - Tennessee and Wisconsin, April-September 2020. MMWR. Morbidity and Mortality Weekly Report, 69 (2020) 1631-1634. https://doi.org/10.15585/mmwr.mm6944e1.

21. Z. Wang, W. Ma, X. Zheng, G. Wu, \& R. Zhang, Household transmission of SARS-CoV-2. Journal of Infection, 81 (2020) $179-182$. https://doi.org/10.1016/j.jinf.2020.03.040.

22. Z. J. Madewell, Y. Yang, I. M. Longini, M. E. Halloran, \& N. E. Dean, Household Transmission of SARS-CoV-2: A Systematic Review and Meta-analysis. JAMA network open, 3 (2020) e2031756. https://doi.org/10.1001/jamanetworkopen.2020.31756.

23. R. Cohen, C. Jung, N. Ouldali, A. Sellam, C. Batard, F. Cahn-Sellem, A. Elbez, A. Wollner, O. Romain, F. Corrard, S. Aberrane, N. Soismier, R. Creidy, M. Smati-Lafarge, O. Launay, S. Béchet, E. Varon, \& C. Levy, Assessment of SARS-CoV-2 infection by Reverse transcription-PCR and serology in the Paris area: A cross-sectional study. BMJ Paediatrics Open, 4 (2020) 1-7. https://doi.org/10.1136/bmjpo-2020-000887.

24. R. M. Viner, O. T. Mytton, C. Bonell, G. J. Melendez-Torres, J. Ward, L. Hudson, C. Waddington, J. Thomas, S. Russell, F. Van Der Klis, A. Koirala, S. Ladhani, J. Panovska-Griffiths, N. G. Davies, R. Booy, \& R. M. Eggo, Susceptibility to SARS-CoV-2 Infection among Children and Adolescents Compared with Adults: A Systematic Review and Meta-analysis. JAMA Pediatrics, (2020) 1-14. https://doi.org/10.1001/jamapediatrics.2020.4573.

25. K. Shah, Y. Kandre, \& D. Mavalankar, Secondary attack rate in household contacts of COVID-19 Paediatric index cases: a study from Western India. Journal of Public Health, (2021) 1-3. https://doi.org/10.1093/pubmed/fdaa269.

Page $15 / 19$ 
26. P. Zimmermann \& N. Curtis, Why is COVID-19 less severe in children? A review of the proposed mechanisms underlying the agerelated difference in severity of SARS-CoV-2 infections. Archives of Disease in Childhood, (2020) 1-11.

https://doi.org/10.1136/archdischild-2020-320338.

27. Gobierno de Canarias. ISTAC. (2021). .

28. J. P. Torres, C. Piñera, V. De La Maza, A. J. Lagomarcino, D. Simian, B. Torres, C. Urquidi, M. T. Valenzuela, \& M. O’Ryan, Severe Acute Respiratory Syndrome Coronavirus 2 Antibody Prevalence in Blood in a Large School Community Subject to a Coronavirus Disease 2019 Outbreak: A Cross-sectional Study. Clinical Infectious Diseases, (2020). https://doi.org/10.1093/cid/ciaa955.

29. S. L. Klein, A. Pekosz, H. S. Park, R. L. Ursin, J. R. Shapiro, S. E. Benner, K. Littlefield, S. Kumar, H. M. Naik, M. J. Betenbaugh, R. Shrestha, A. A. Wu, R. M. Hughes, I. Burgess, P. Caturegli, O. Laeyendecker, T. C. Quinn, D. Sullivan, S. Shoham, A. D. Redd, E. M. Bloch, A. Casadevall, \& A. A. R. Tobian, Sex, age, and hospitalization drive antibody responses in a COVID-19 convalescent plasma donor population. medRxiv, 130 (2020). https://doi.org/10.1101/2020.06.26.20139063.

30. S. Elahi, Neonatal and Children's Immune System and COVID-19: Biased Immune Tolerance versus Resistance Strategy. The Journal of Immunology, 205 (2020) 1990-1997. https://doi.org/10.4049/jimmunol.2000710.

31. H. S. Yang, V. Costa, S. E. Racine-Brzostek, K. P. Acker, J. Yee, Z. Chen, M. Karbaschi, R. Zuk, S. Rand, A. Sukhu, P. J. Klasse, M. M. Cushing, A. Chadburn, \& Z. Zhao, Association of Age With SARS-CoV-2 Antibody Response. JAMA Network Open, 4 (2021) e214302. https://doi.org/10.1001/jamanetworkopen.2021.4302.

32. S. P. Weisberg, T. J. Connors, Y. Zhu, M. R. Baldwin, W. H. Lin, S. Wontakal, P. A. Szabo, S. B. Wells, P. Dogra, J. Gray, E. Idzikowski, D. Stelitano, F. T. Bovier, J. Davis-Porada, R. Matsumoto, M. M. L. Poon, M. Chait, C. Mathieu, B. Horvat, D. Decimo, K. E. Hudson, F. D. Zotti, Z. C. Bitan, F. La Carpia, S. A. Ferrara, E. Mace, J. Milner, A. Moscona, E. Hod, M. Porotto, \& D. L. Farber, Distinct antibody responses to SARS-CoV-2 in children and adults across the COVID-19 clinical spectrum. Nature Immunology, 22 (2021) 25-31. https://doi.org/10.1038/s41590-020-00826-9.

33. P. L. Fidel \& M. C. Noverr, Could an unrelated live attenuated vaccine serve as a preventive measure to dampen septic inflammation associated with covid-19 infection? mBio, 11 (2020) 1-4. https://doi.org/10.1128/mBio.00907-20.

34. C. King \& J. Sprent, Dual Nature of Type I Interferons in SARS-CoV-2-Induced Inflammation. Trends in Immunology, 42 (2021) 312322. https://doi.org/10.1016/j.it.2021.02.003.

35. A. Wang, J. Chiou, O. B. Poirion, J. Buchanan, M. J. Valdez, J. M. Verheyden, X. Hou, P. Kudtarkar, S. Narendra, J. M. Newsome, M. Guo, D. A. Faddah, K. Zhang, R. E. Young, J. Barr, E. Sajti, R. Misra, H. Huyck, L. Rogers, C. Poole, J. A. Whitsett, G. Pryhuber, Y. Xu, K. J. Gaulton, S. Preissl, \& X. Sun, Single-cell multiomic profiling of human lungs reveals cell-type-specific and age-dynamic control of sarscov2 host genes. elife, 9 (2020) 1-28. https://doi.org/10.7554/eLife.62522.

36. N. Saheb Sharif-Askari, F. Saheb Sharif-Askari, M. Alabed, M. H. Temsah, S. Al Heialy, Q. Hamid, \& R. Halwani, Airways Expression of SARS-CoV-2 Receptor, ACE2, and TMPRSS2 Is Lower in Children Than Adults and Increases with Smoking and COPD. Molecular Therapy - Methods and Clinical Development, 18 (2020) 1-6. https://doi.org/10.1016/j.omtm.2020.05.013.

37. A. Heurich, H. Hofmann-Winkler, S. Gierer, T. Liepold, O. Jahn, \& S. Pohlmann, TMPRSS2 and ADAM17 Cleave ACE2 Differentially and Only Proteolysis by TMPRSS2 Augments Entry Driven by the Severe Acute Respiratory Syndrome Coronavirus Spike Protein. Journal of Virology, 88 (2014) 1293-1307. https://doi.org/10.1128/jvi.02202-13.

38. Y. Hou, J. Zhao, W. Martin, A. Kallianpur, M. K. Chung, L. Jehi, N. Sharifi, S. Erzurum, C. Eng, \& F. Cheng, New insights into genetic susceptibility of COVID-19: An ACE2 and TMPRSS2 polymorphism analysis. BMC Medicine, 18 (2020) 1-8. https://doi.org/10.1186/s12916-020-01673-z.

\section{Figures}




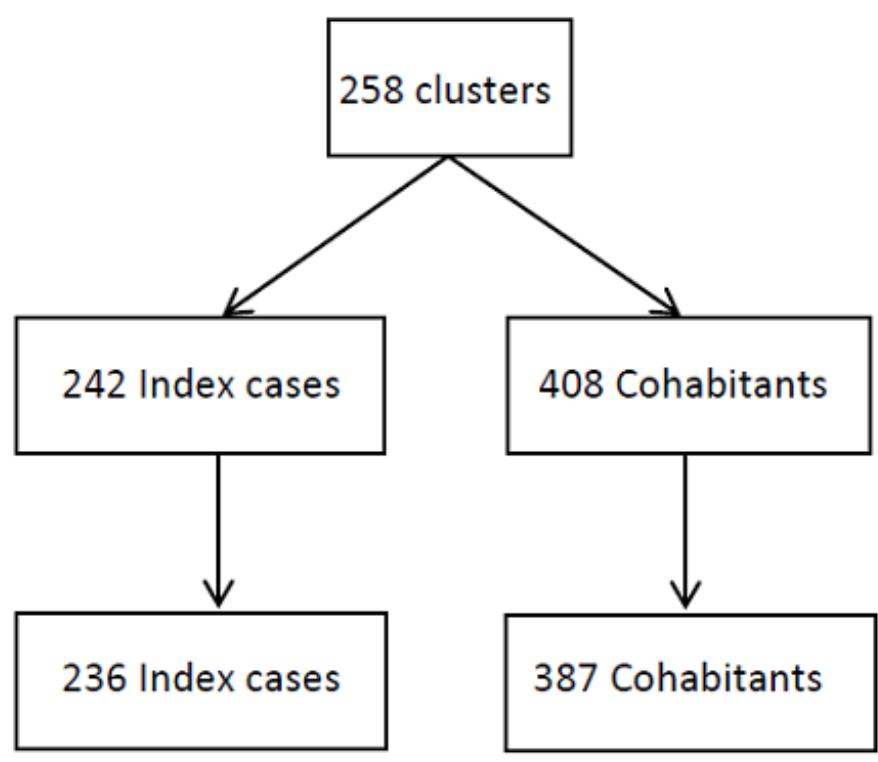

\section{Filled out the questionnaire}

Undertook serology testing

\section{Figure 1}

Summary of study participants
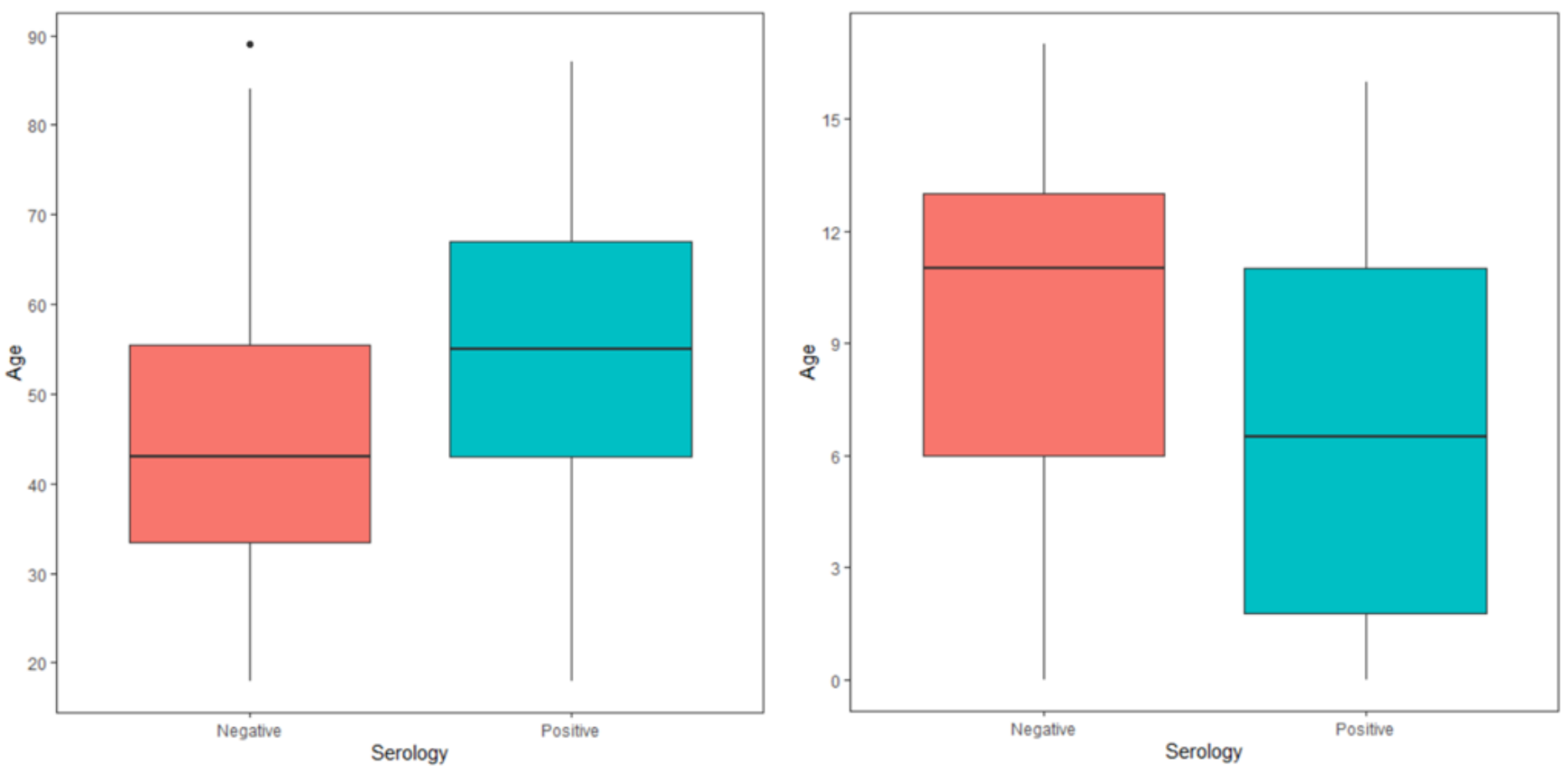

Figure 2

Age difference between patients with negative and positive serologic results in adults(a) and children(b). 


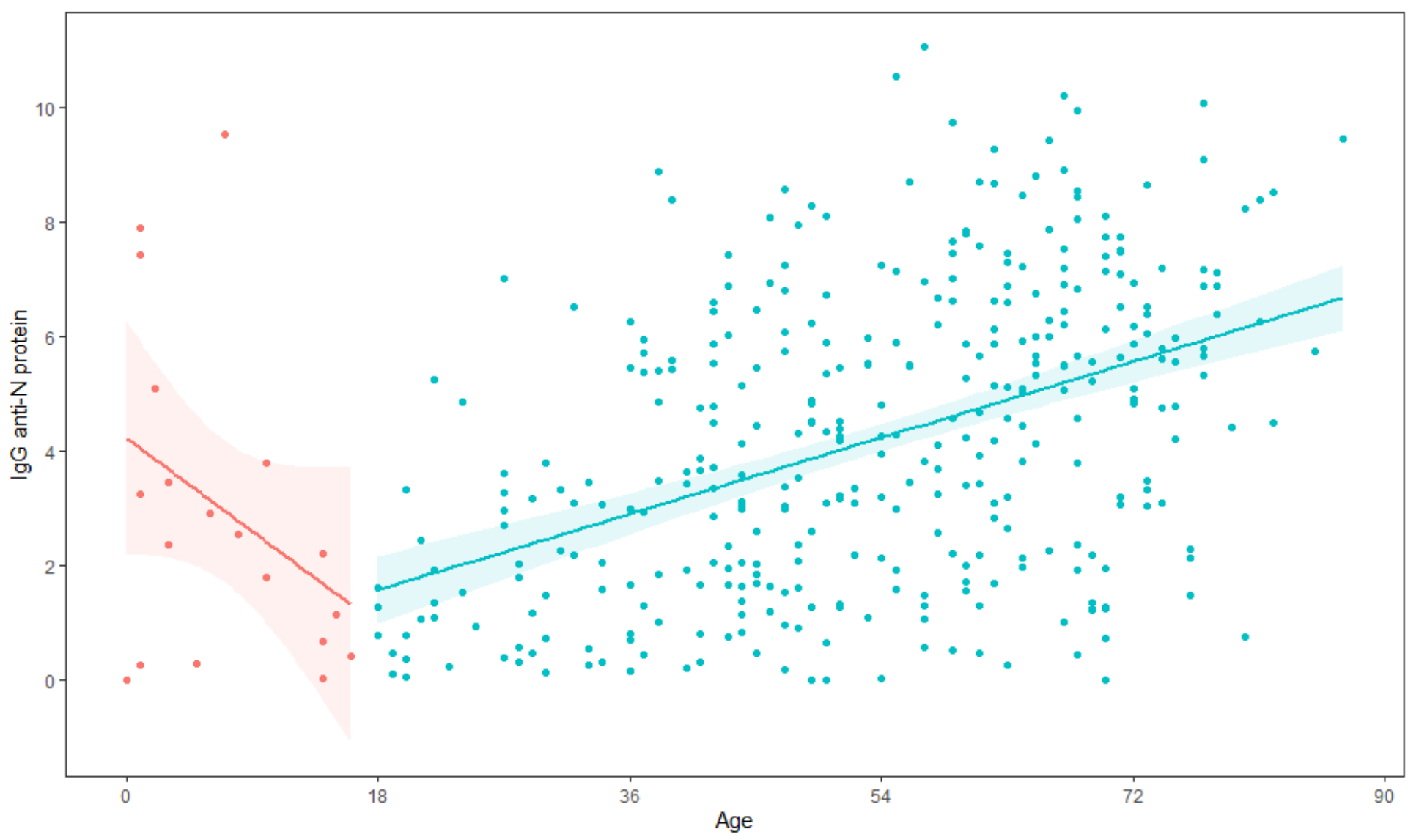

Figure 3

Correlation between age and antibody indexes in both children and adults.
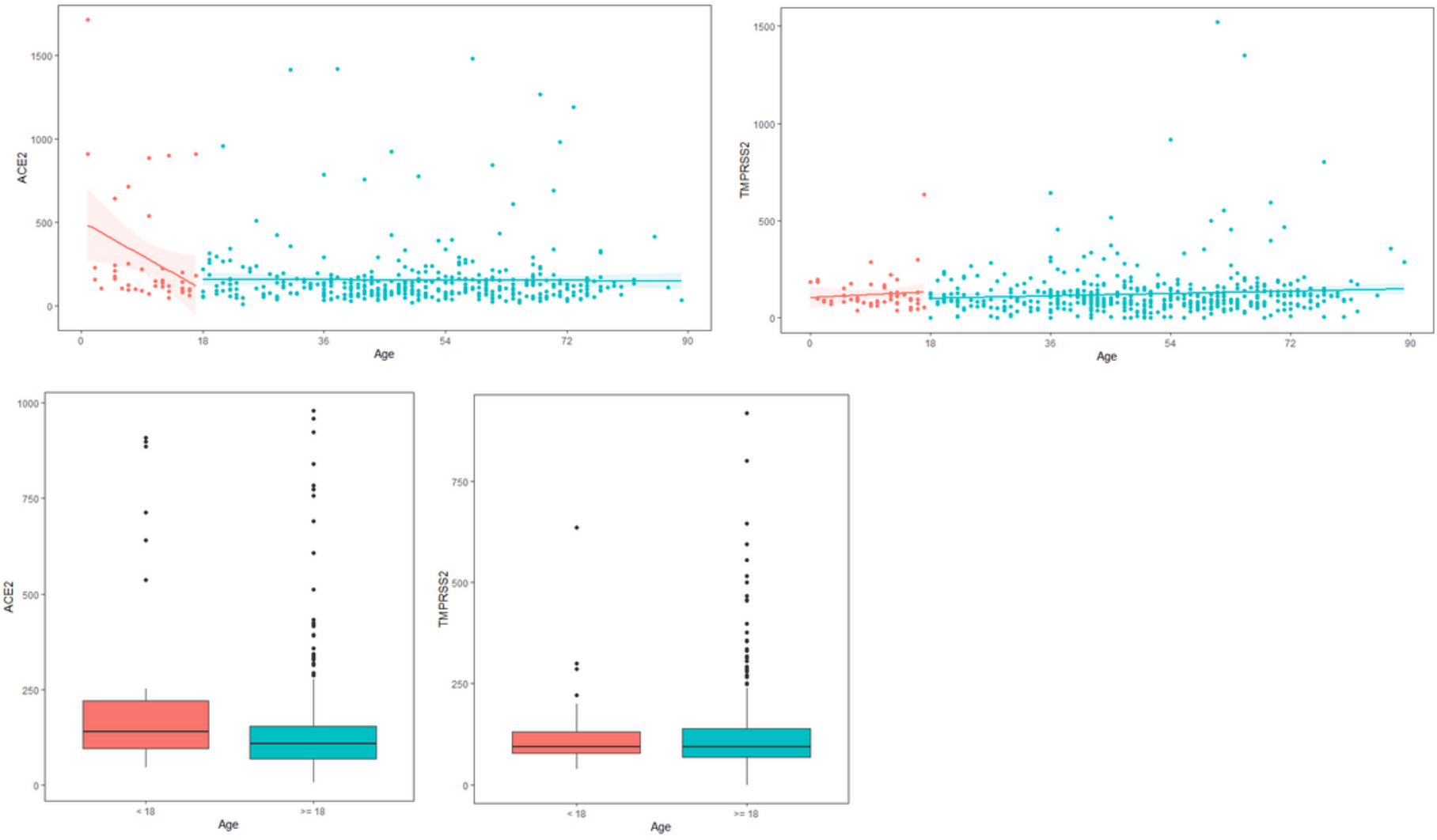


\section{Figure 4}

Correlation between age and ECA2 and TMPRSS2 protease expression (a) Correlation between age and ECA2 and TMPRSS2 expression. (b) Comparison between ACE2 and TMPRSS2 expression in children and adults.

\section{Supplementary Files}

This is a list of supplementary files associated with this preprint. Click to download.

- Image1.png 